International Journal of Social Science And Human Research

ISSN(print): 2644-0679, ISSN(online): 2644-0695

Volume 03 Issue 08 August 2020

DOI: $10.47191 / \mathrm{ijsshr} / \mathrm{v} 3-\mathrm{i} 8-02$

Page No.- 101-105

\title{
Competency of Overseas Student in Overcoming the Culture Shock Among Indonesian Students
}

\author{
Rahmadya Putra Nugraha ${ }^{1}$, Nor Fauziana Ibrahim ${ }^{2}$, Tai Hen Toong ${ }^{3}$ \\ ${ }^{1}$ Mercu Buana University, Jakarta, Indonesia \\ ${ }^{2,3}$ Multimedia University, Melaka, Malaysia
}

\begin{abstract}
Communication is an important thing in interacting with fellow humans. Intercultural communication is a communicatioan betweens peoples with different culture. In the process, constrains is often encountered oobstacles which can hinder the intercultural communication process. These constraints can obtained from the different cultural environment or from people's psychologisc. One of the cultural communication problem is culture shock. This research will describe and explain the competence of Mercu Buana University's overseas students to overcome culture shock in new environment.

This research is an constructivist type, research that seeks to understand the people's environment and develop subjective meaning. Moreover, this research is derciptive type with qualitative approach. Descriptive is aim to collect, explain, and summarize a data towards the subject under study. Qualitative is an indeep research and analysis of collected data. The research methods is case study taht collect, organize, and analyze data about certain cases.

The research result is, everey overseas students has their own methods to handle culture shock and adapting with new environment. The first thing that became a challenge for overseas students is the different culture. The different culture make some overseas students feels worry, homesick, and culture shock. But they can handle the problems, they try to develop the competence of communication in order to adapt with new environment.
\end{abstract}

Key Words : Intercultural Communication, Overseas Students, Culture Shock

\section{INTRODUCTION}

Communication competence is needed as a provision for individuals who will move to areas that have cultures that are different from their original culture. Communication competence is the ability of individuals to overcome obstacles to communicate with other individuals without feeling pressured and burdened. Someone who has good competence will easily adapt to the new environment, and it is easy to overcome the cultural shock that is owned by someone who has just moved from a certain area.

As a person's ability to transfer and apply these skills and knowledge in new situations and increase agreed benefits. Competence also shows the characteristics of the knowledge and skills that are owned and needed by each individual who enables them to communicate with people in their new environment.(Nelfianti, Yuniasih, \& Wibowo, 2018)

Cultural shock is caused by anxiety caused by loss of signs and symbols in social interaction. These signs are an activity or things we usually do in controlling ourselves in the face of everyday situations. Likewise, other aspects of our culture such as our language and the beliefs that we embrace.

To overcome cultural shock because it interacts with the new environment and culture, adaptation through communication competencies can be done by migrants with their own ways, such as learning the local language, understanding the character / nature of the community, having good relations with the host, being good at responding when carrying out the communication process, understanding the norms of what may and may not be done, and most importantly having the motivation to communicate with the local community.

\section{LITERATURE REVIEW \\ Communication}

Communication is a process that is ongoing and always moving, moving increasingly forward and changing continuously. Communication occurs in a system of interconnected parts that affect each other. Communication emphasizes the role of symbols that include nonverbal language and behavior, as well as art and music. Something abstract indicates something else can be a symbol. (Wood, 2009) 
Communication is an important thing that happens in community life between individuals with each other. By communicating, people will better understand each other's needs. Communication continues in human life and continues to grow. Without communication, human relations with one another will be hampered.

The importance of communication for social, cultural, educational and political life has been realized by scholars since Aristotle who lived hundreds of years before Christ. However, Aristosteles' study only revolved around rhetoric in a small environment. The object of communication science study not only conveys information, but also the formation of public opinion and public attitude which in a social and political life plays a very important role. (Uchjana, 2011)

Communication that occurs in social life does not only revolve in one direction or only as a transmitter of information, but besides that, there is also feedback and of course the perceptions and views of each individual will be formed, because basically the individual's thoughts on things are different.

\section{Culture}

Culture is basically values that arise from the process of interaction between individuals. These values are recognized, both directly and indirectly, along with the time passed in the interaction. Sometimes even that value takes place in the individual's subconscious and bequeathed to the next generation. (A. Siregar, 2014)

Culture is a set of life views from the community, starting from, beliefs, forms of behavior, values, experiences, knowledge, attitudes, meanings, concepts of the universe, which have been embedded and passed down from generation to generation through imitation because it has become a habit in life the community.

In the view of psychology, as popularized by Geert Hofstede (Hofstede, 2009), culture is interpreted not merely as a response from human thinking or "programming of the mind", but also as an answer or response from human interaction involving certain patterns as group members in responding to the environment in which humans are located.

Culture can also be created from values that arise due to interactions between people in a particular area, because culture is inseparable from human life. In fact, the slightest human behavior can be considered as a culture of man himself, such as the way he walks, the way he eats, the way he speaks, etc., because culture is a reflection of human behavior which becomes his daily habit.

There is no society that does not have culture or vice versa, culture also cannot stand alone without society, both are interconnected with one another. Every day people create new cultures in their lives. In everyday life, humans cannot not deal with the results of culture. Every human being sees, uses, and sometimes even destroys existing cultures.

\section{Intercultural Communication}

Intercultural communication is communication carried out by people who have different cultural backgrounds. These differences include the nation, ethnicity, race, country, or even regions that have a thick culture. Communication that arises in intercultural communication among these people is affected by one another. The culture between the two can also be affected by the communication process carried out.(Kotthoff \& Spencer-Oatey, 2008)

Intercultural communication is a term that includes general meaning and shows communication between people who have different cultural backgrounds. In its development, intercultural communication is often "equated" with cross-cultural communication. Cross-cultural communication focuses its discussion on comparing communication phenomena in different cultures. For example, how is the style of male communication or the style of communication of women in American culture and Indonesian culture. (Sobarudin, 2019)

Often, individuals or communicators who want to communicate with other individuals who have different cultures experience difficulties because they feel there is a barrier between them, such as differences in language, perspective, behavior, and thinking about something. Because of this, communicators need to understand the function of intercultural communication so that there is no misunderstanding in the perception of the message to be conveyed.

\section{Cultural Shock Reactions and Symptoms}

M.E. Ryan and R.S. Twibell said that the reactions associated with culture shock vary among individuals and can appear at different times. For example, someone who is constantly in touch with another culture might be a little nervous. According to Ryan and Twibell, culture shock requires some adjustments before you can finally adapt to the new environment. This adjustment can be in the form of communication problems, mechanical and environmental differences, isolation and experience of cultural differences, behaviors, and beliefs. This gives rise to different individual reactions.(Twibell \& Ryan, 2000)

There are several symptoms of culture shock that can be experienced by individuals who are in a new environment (Guanipa, 1998; Khoirun Niam, 2009), including:

1) Sadness, loneliness, and humility

2) Preoccupation (the mind is fixed only on an idea, which is usually associated with an emotional state) with health.

3) Difficulty in sleeping, sleeping too much or too little

4) Changes in behavior, pressure or depression 
5) Anger, quick temper, reluctance to connect with other people

6) Identifying the old culture or idealize the old area

7) Loss of identity

8) Trying too hard to absorb everything in a new culture

9) Not able to solve simple problems

10) Not confident

11) Feeling lack, loss and anxiety

12) Developing stereotypes about new cultures

13) Developing obsessions such as over-cleanliness

14) Missing the family

According to anthropologists, cultural shock begins with an identity crisis, where this identity crisis can befall anyone when he migrates. Migration here cannot be seen geographically, but more emphasis is placed on cultural migration to foreign cultures which often paralyzes one's role, identity and even self-esteem. (Sobarudin, 2019)

Cultural shock is usually experienced by someone who moves to an area that has a culture that is very different from its own culture. Like students who want to continue their education in other regions or countries. The culture shock that arose in the student came from his new environment and was driven by feelings of loneliness because it was far from the closest people who had been in his life.

\section{METHODOLOGY}

This research uses the Constructivism paradigm or social constructivism with descriptive study with a qualitative approach, namely research that describes the nature of a situation that is temporarily running at the time research was conducted and examined the causes of a particular symptom. (Steinfatt \& Millette, 2019). In this study the research method used was a Case study. Case studies are casual-oriented methods of the units being studied with regard to the issues that are the focus of research.(Brouwer \& Asen, 2010)

The research subject is something that is examined by people, objects, or institutions (organizations). In this study, the subjects taken were humans, more specifically the overseas students and also cultural students.

\section{RESEARCH FINDING}

The communication competencies owned by each individual, especially for migrants, are different each other. Humans have their own way of dealing with problems that occur during the process of adaptation regarding wander. Based on the consensus of the experts, intercultural communication competence has five basic components, namely motivation to communicate, sufficient knowledge about culture, appropriate communication skills, and sensitivity in the cultural environment, and character of a migrant.

From the results of the study and interviews conducted on the six wander students, it can be seen that they owned five components of intercultural communication competence with different perspectives and adjustments in each individual. For example, the component of motivation to communicate by paying attention to the local community communication, the component of sufficient knowledge about culture by knowing the differences in language and relationship patterns, the component of appropriate communication skills by having a lot of communication with the local community, the component sensitivity in the cultural environment by not imposing a certain culture, and the component of the character of a migrant by upholding the value of courtesy.

Study on the communication competencies among wander students to overcome the culture shock in their new environment is subjective, meaning that each individual has his own experience and views on his communication competence. It is similar to constructivism or social construction which explains that humans are formed based on the experience in which they pass and that experience becomes new knowledge for themselves. J Piaget, known as the first originator of constructivism, assert that knowledge is built through assimilation which is the absorption of new information and accommodation that rearranges thinking due to new information. In this case, wander students experience and feel their own experience in adapting to their new environment. During the process, the wander students slowly build new social and cultural knowledge in the new area they enter into.

As revealed by Patton that case studies are an effort to collect, organize and analyze data about certain cases regarding issues of concern to researchers and then the data is compared or linked with one another while still adhering to the holistic principle and contextual. The current researcher tried to learn the problem of communication competencies in the adaptation process through the experiences that had been passed by wander students. There were various experiences passed by wander students, there were obstacles that must be passed and it is important to think how the communication competencies were carried out in order to adapt to the new environment. The data obtained were then compared and connected between wander students with one another.

Jakarta as the Capital City has a strong appeal for migrants to try their luck and study. Jakarta has a diverse cultural community due to the high flow of urbanization. The movement of people from other region to Jakarta is triggered since Jakarta 
offered various facilities that are easily obtained by the community. In this study, Jakarta is a city chosen by the six interviewees. Each wander student had their own reasons for deciding to migrate to the capital city, such as, to pursue their dreams, find networking, get new experiences, explore themselves, and so on. However, during their wandering period, there were problems that arose due to cultural differences. Cultural differences that existed often hindered the process of adaptation undertaken by wander students. The problems were related to language and the patterns of interaction and relationships that were quite different from one another.

Often a person judges the culture of another person based on his cultural experience. When someone is in a different cultural environment, that person tends to compare with his culture. The attitude of seeing and interpreting other people's behavior based on cultural values is called ethnocentrism. According to Brigham (1991), ethnocentrism is very close and often inseparable from socalled stereotypes. Stereotypes are the generation of attitudes, beliefs, or opinions about people from other cultures. From the interviews conducted by researchers with wander students, when they first set foot and become acquainted with the social culture in Jakarta, Wander students tended to assess the behavior patterns and relationships of the people of Jakarta subjectively by comparing it with their own culture. Cultural differences felt by wander students become one of the problems in adapting to the new environment. But over time, wander students tried to understand and learn the culture and language that existed in their wander environment.

Besides, the adaptation barriers felt by wander students came from within themselves, such as difficulty in communicating, experiencing anxiety about things and life related to their new environment, anxiety about relationships in the new environment, anxiety about the lives of the closest people in their hometowns, and those conditions gave rise to homesickness or longing for the atmosphere of the house and the desire to go home, they also felt the culture shock and other psychological feelings. According to wander students, psychological problems they experienced were commonplace things and they did't allow the problems to drag on. They tried to overcome these problems by their own way so that the adaptation carried out in the new environment run smoothly and did not hamper their social life and developed interactions.

Culture shock is a situation where a person or group of people is faced with a new culture and there is a clash and incompatibilty of cultures with the old culture they have, because they are not fully ready to accept the differences that exist in the new culture. Culture shock can cause feelings of anxiety, restlesness, and loss of self-confidence. Culture shock can happen to anyone. By first learning and understanding the new culture that will be entered, the presence of culture shock can be minimized.

Communication is important in supporting the adaptation process. According to Judee Burgoon in her theory of interaction adaptation, it is stated that communication is expressed as a form of adaptation. This theory also explains that adopting the language in the new environment should be done by the migrants so that communication with the local community can run smoothly. In addition, understanding the character of communication is important in the process of intercultural communication. Understanding one's communication character will also decrease the level of misunderstanding that occurs while communicating and interacting. Understanding the character of each individual can be done by expanding our circle of friends. Communication can be carried out without any obstacles if one can understand the character of many people who have different cultures.

Someone who moves from one region to another with a different culture often encounters psychological problems in the adaptation process. As explained earlier, psychological problems such as anxiety, homesickness, and culture shock can be overcome by strengthening communication competencies so that the problems that arise due to psychological barriers during the interactions conducted may be eliminated. Migrants have their own communication competencies to harmonize the interaction process being carried out. One of the competencies of communication carried out is by learning the local culture and language and understanding the cultural character of the local community.

During the adaptation process, cultural adoption is often performed by migrants, both consciously and unconsciously. The cultural adoption leads to changes in culture and behavior patterns that exist among the migrants. These changes include changes in the character in a person such as, become braver, have the ability to survive in all circumstances, changes in the mindset, being independent, and changes in interaction behavior such as, more open in communication, maintain behavior and politeness better, broader circle of relationships, and can solve their own problems.

\section{CONCLUSION}

Adaptation is an important thing that must be possessed by a migrant. However during the process, there are obstacles faced by migrants to finally be able to adapt to the new environment they enter. A good intercultural communication competency is required by a migrant so that the interaction that exists with the local community can run smoothly and adaptation process can be carried out properly. The following are conclusions derived from the results and discussion of the study on communication competencies of overseas students to overcome the culture shock within their new environment:

1. The six overseas students had five basic components of intercultural communication competence with different perspectives and adjustments in each individual. These components included motivation to communicate, sufficient knowledge of culture, appropriate communication skills, sensitivity to culture, and overseas individual character. 
2. In the process of adaptation, overseas students often encountered cultural changes within themselves because the new culture that entered influenced the old culture that already existed for a long time. These changes included changes in attitudes, mindsets, habits, language use, and other aspects of culture.

\section{REFERENCES}

1) A. Siregar, Q. (2014). Komunikasi Antarbudaya (Di Era Budaya Siber). Jurnal Sosioteknologi. https://doi.org/10.5614/sostek.itbj.2014.13.3.10

2) Brouwer, D. C., \& Asen, R. (2010). Introduction: Public modalities, or the metaphors we theorize by. Public Modalities: Rhetoric, Culture, Media, and The Shape of Public Life.

3) Hofstede, G. (2009). Geert Hofstede Cultural Dimensions. Itim International. https://doi.org/10.1093/oxfordhb/9780199585762.013.0019

4) Kotthoff, H., \& Spencer-Oatey, H. (2008). Handbook of intercultural communication. Handbook of Intercultural Communication. https://doi.org/10.1016/j.system.2010.09.007

5) Nelfianti, F., Yuniasih, I., \& Wibowo, A. I. (2018). Pengaruh Budaya Organisasi Terhadap Kinerja Karyawan YPI Cempaka Putih Jakarta. Jurnal Kajian Ilmiah. https://doi.org/10.31599/jki.v18i2.202

6) Sobarudin, K. (2019). Konsep Dan Dinamika Komunikasi Antarbudaya di Indonesia. Jurnal Dakwah Dan Komunikasi. https://doi.org/10.29240/jdk.v4i1.886

7) Steinfatt, T. M., \& Millette, D. M. (2019). Intercultural communication. In An Integrated Approach to Communication Theory and Research, Third Edition. https://doi.org/10.4324/9780203710753-26

8) Twibell, R. S., \& Ryan, M. E. (2000). Concerns, values, stress, copying, health and educational outcomes of college students who studied abroad. International Journal of Intercultural Relations.

9) Uchjana, E. O. (2011). Ilmu Komunikasi. Ilmu Komunikasi. https://doi.org/10.1055/s-2008-1040325

10) Wood, J. T. (2009). The Study of Communication, Gender, and Culture. Gendered Lives: Communication, Gender, and Culture, 8th Edition. 